\title{
Efektivitas Media Lagu Dalam Pembelajaran Daring Sebagai Upaya Meningkatkan Kemampuan Menulis Surat Pribadi Siswa SMP
}

\author{
Valentinus Ola Beding \\ STKIP Persada Khatulistiwa \\ valentinus.beding86@gmail.com
}

\begin{abstract}
This study aims to improve students' ability in writing personal letters using song media. The media used in this research were Melly Goeslow's song "Bunda" and the song "Titip Rindu Untuk. Ayah by Ebiet G. Ade. The form of the research is Classroom Action Research which is carried out in two cycles, with each cycle consisting of action planning, action implementation, observation and interpretation, as well as analysis and reflection. Sources of data are in the form of learning events, informants, and documents. The data collection techniques used were observation, in-depth interviews, tests, and document analysis. The validity of the data used was data triangulation and method triangulation. The percentage of students who completed writing personal letters in the first cycle was $62.95 \%$ and $88.89 \%$ in the second cycle. Student responses to the use of song media in learning to write personal letters are positive because in interviews students feel happy, confident and able to understand how to write personal letters.
\end{abstract}

Keywords: songs media; online learning; writing; personal letters

\begin{abstract}
ABSTRAK
Penelitian ini bertujuan untuk meningkatkan kemampuan siswa dalam menulis surat pribadi dengan menggunakan media lagu. Media yang digunakan dalam penelitian ini adalah media lagu "Bunda" karya Melly Goeslow dan lagu "Titip Rindu Buat Ayah karya Ebiet G. Ade. Bentuk penelitian merupakan Penelitian Tindakan Kelas yang dilaksanakan dalam dua siklus,dengan tiap siklus terdiri atas perencanaan tindakan, pelaksanaan tindakan, observasi dan interpretasi, serta analisis dan refleksi. Sumber data berupa peristiwa pembelajaran, informan, dan dokumen. Teknik pengumpulan data yang digunakan adalah observasi, wawancara mendalam, tes, dan analisis dokumen. Validitas data yang digunakan adalah triangulasi data dan triangulasi metode. Persentase siswa tuntas menulis surat pribadi pada siklus I adalah $62,95 \%$ dan pada siklus II 88,89\%. Respon siswa terhadap penggunaan media lagu dalam pembelajaran menulis surat pribadi adalah positif karena dalam wawancara siswa merasa senang, dan percaya diri serta mampu memahami cara menulis surat pribadi.
\end{abstract}

Kata Kunci: media lagu; pembelajaran daring; menulis; surat pribadi

Submitted May 12, 2021 | Revised Jun 03, 2021 | Accepted Jun 07, 2021

\section{Pendahuluan}

Rendahnya kualitas hasil dan proses belajar masih menjadi salah satu permasalahan yang sering dihadapi dalam dunia pendidikan. Rendahnya kualitas hasil belajar ditandai oleh pencapaian prestasi belajar yang belum memenuhi standar kompetensi seperti tuntutan kurikulum (Sanjaya, 2011). Dalam hal ini siswa sebenarnya diharapkan dapat mencapai kompetensi, yakni perpaduan pengetahuan, sikap, dan keterampilan yang terefleksi dalam kehidupan sehari-hari.

Rendahnya kualitas hasil dan proses pembelajaran juga terjadi pada pembelajaran Bahasa Indonesia. Keterampilan berbahasa mempunyai empat komponen, yaitu kemampuan menyimak, kemampuan berbicara, kemampuan membaca, dan kemampuan menulis. Keempat kemapuan tersebut pada dasarnya merupakan satu kesatuan. Keempat kemampuan tersebut berkaitan erat dan saling berhubungan (Tarigan, 2008).

Sebagai salah satu aspek dari keterampilan berbahasa, menulis atau mengarang merupakan kegiatan yang kompleks (Maryam, 2016; Trismanto, 2017). Kompleksitas menulis terletak pada tuntutan kemampuan untuk menata dan mengorganisasikan ide secara runtut dan logis, serta menyajikannya dalam ragam bahasa tulis dan kaidah penulisan lainnya (Kasili, et al, 2017). Akan tetapi, dibalik kerumitannya, menulis menjanjikan manfaat yang begitu besar dalam membantu pengembangan 
daya inisiatif dan keativitas, kepercayaan diri dan keberanian, serta kebiasaan dan kemampuan dalam menemukan, mmengumpulkan, mengolah, dan menata informasi.

Menulis sebagai salah satu keterampilan berbahasa tidak dapat dilepaskan dari aspek-aspek keterampilan berbahasa lainnya. Ia mempengaruhi dan dipengaruhi. Pengalaman dan masukan yang diperoleh dari menyimak, berbicara, dan membaca, akan memberikan kontribusi berharga dalam menulis (Sianturi, 2012; Fajriah, 2017). Begitu pula sebaliknya, apa yang diperoleh dari menulis akan berpengaruh pula terhadap ketiga corak kemampuan berbahasa lainnya. Sifat aktif, produktif, dan tulis dalam menulis, memberikannya ciri khusus dalam hal kecaraan, medium, dan ragam bahasa yang digunakannya.

Menulis adalah melukiskan lambang-lambang grafik yang menggambarkan suatu bahasa yang dipahami oleh seseorang, sehingga mereka memahami bahasa dan gambaran grafik tersebut (Tarigan, 2008). Gambaran atau lukisan dapat menyampaikan makna-makna, tetapi tidak menggambarkan kesatuan-kesatuan bahasa. Oleh sebab itu, menulis dan melukis itu berbeda. Komunikasi melalaui tulisan bersifat tidak langsung, maka menulis tidak dapat mengeksprisikannya dengan unsur-unsur pembantu komunikasi lainnya, seperti mimik wajah, gerak anggota tubuh, dan nada suara.

Salah satu kesulitan menulis yang dihadapi siswa adalah menulis surat pribadi. Surat pribadi merupakan surat yang dibuat oleh seseorang atas nama pribadi dan ditujukan kepada orang lain, seperti saudara atau teman dengan tujuan tertentu (Lestari, et al., 2005). Surat pribadi adalah tulisan yang berisi tentang maksud atau tujuan tertentu atau tulisan yang bertujuan untuk menyampaikan informasi kepada penerima pesan. Surat yang dikatakan baik apabila penerima surat memahami dengan tepat isi surat yang diterimanya. Maksud penulis surat tersampaikan dengan tepat kepada pembaca. Oleh karena itu, surat yang baik harus memenuhi kriteria, yaitu benar, jelas, dan lengkap.

Berdasarkan hasil observasi awal bersama guru mata pelajaran Bahasa Indonesia di SMP Nusantara Indah, keterampilan menulis siswa masih dikatakan rendah. Dikatakan rendah karena siswa masih terlihat kurang memahami kelengkapan unsur, gaya penulisan, ejaan dan tanda baca, serta penyampaian dalam menulis, ditambah lagi kondisi pembelajaran secara daring yang mana siswa belajar tidak bertatap langsung dengan guru di kelas tetapi secara daring.

Beberapa penelitian sebelumnya telah dilakukan untuk mengatasi rendahnya kemampuan menulis siswa. Para peneliti berhasil meningkatkan kemampuan menulis siswa dengan menerapkan model, metode atau strategi pembelajaran, diantaranya metode picture and picture ((Mundziroh, et al, 2013), pembelajaran kooperatif melalui teknik duti-duta (San Fauziya, 2018), Model Pembelajaran Kooperatif Terpadu (Samsudin, 2012), dan model pembelajaran berbasis proyek (Baidowi, et al, 2016). Di samping itu, ada juga penelitian yang berupaya meningkatkan kemampuan menulis siswa dengan menggunakan media pembelajaran, diantaranya Media Scrapbook (Heryaneu, 2014), media audiovisual (Andyani, et al, 2017), media gambar berseri (Salfera, 2017), dan Media Video Faststone (Darmuki, et al, 2021). Dalam penelitian ini, penulis menggunakan media lagu sebagai upaya dalam meningkatkan kemampauan menulis siswa, dalam hal ini surat pribadi siswa.

Media lagu merupakan sarana tepat yang bisa dimanfaatkan untuk menggugah ide serta minat siswa dalam menulis pribadi. Dalam sebuah lagu terdapat berbagai macam diksi yang bisa memberikan suguhan kata-kata yang membantu pembuatan surat bagi siswa. Lagu sangat dekat dengan siswa, tetapi siswa terkadang kurang memperhatikan isi dan cerita yang terdapat dibalik lirik-liriknya. Melalui lagu, siswa akan terbawa suasana hatinya ke dalam alunan kata-kata yang ada sehingga diharapkan siswa mampu menuliskan sebuah cerita pendek sesuai dengan tema lagu yang telah ditentukan (Jumaryatun, 2014). Aizid (2011) menyatakan bahwa lagu atau musik dapat meningkatkan intelegensi karena rangsangan ritmis mampu meningkatkan fungsi kerja otak manusia, seperti membuat saraf-saraf otak bekerja serta menciptakan rasa nyaman dan tenang sehingga fungsi kerja otak menjadi optimal. Rangsangan ritmis dari lagu yang diperdengarkan itulah yang dapat meningkatkan kemampuan berbahasa, kreativitas, konsentrasi, dan daya ingat. 
Media lagu merupakan media audio yang mampu merangsang indra pendengar karena media ini memiliki unsur-unsur pada pendengaran (Djamarah, 2006). Lagu atau musik dapat meningkatkan intelegensi karena rangsangan ritmis mampu meningkatkan fungsi kerja otak manusia, seperti membuat saraf-saraf otak bekerja serta menciptakan rasa nyaman dan tenangsehingga fungsi kerja otak menjadi optimal (Aizid, 2011). Rangsangan ritmis dari lagu yang diperdengarkan itulah yang dapat meningkatkan kemampuan berbahasa, kreativitas, konsentrasi, dan daya ingat.

Dari penjelasan latar belakang di atas, maka penelitian ini bertujuan untuk meningkatkan kemampuan menulis kelas VII SMP Nusantara Indah Sintang dengan menerapkan media lagu. Penelitian ini diharapkan dapat bermanfaat bagi siswa mengembangkan kemampuan menulisnya sehingga berdampak pada peningkatan hasil belajar siswa.

\section{Metode Penelitian}

Penelitian ini menggunakan penelitian tindakan kelas (PTK). Natawidjaja mengatakan PTK adalah pengkajian terhadap permasalahan praktis yang bersifat situasional dan kontekstual, yang ditujukan untuk menentukan tindakan yang tepat dalam rangka pemecahan masalah yang dihadapi, atau memperbaiki sesuatu (Sukiman, 2011). Pendekatan penelitian yang digunakan adalah kualitatif. Menurut Satori dan Komariah (2009:25), penelitian kualitatif adalah suatu pendekatan penelitian yang mengungkapkan situasi sosial tertentu dengan mendeskripsikan kenyataan secara benar, dibentuk oleh kata-kata berdasarkan teknik pengumumpulan data dan analisis data yang relevan yang diperoleh dari situasi yang alamiah.

Penelitian ini dilaksanakan dalam 2 siklus tiap siklus terdiri dari empat tahap yang mengacu pada model kemmis dan MC taggart yaitu: perencanaan atau planning, tindakan atau Acting, pengamatan atau observing, refleksi atau reflecting. Subyek penelitian ini adalah siswa kelas VII SMP Nusantara Indah Sintang sebanyak 27 orang siswa. Metode pengumpulan data yang digunakan meliputi observasi, wawancara dan tes.

\section{Hasil dan Pembahasan}

Penelitian ini merupakan penelitian tindakan kelas yang dilakukan untuk mengatasi makasalah kualitas pembelajaran, yaitu rendahnya kemampuan menulis siswa. Kegiatan penelitian tidakan ini diawali dengan pra-siklus atau disebut juga pra-tindakan. Pada tahap ini penulis dan guru mata pelajaran berkolaborasi mengamati proses pembelajaran dengan menggunakan aplikasi google classroom dan zoom untuk melihat kemampuan siswa dalam menulis surat pribadi. Proses pembelajaran dilaksanakan seperti biasa dengan penyampaian materi oleh guru lalu kemudian siswa diminta untuk menulis surat pribadi yang ditujukan untuk orang tua masing-masing. Berdasarkan hasil pra-siklus, diperoleh beberapa masalah yang dialami siswa di kelas VII SMP Nusantara Indah Sintang. Hasil tes menunjukkan bahwa dari 27 siswa, hanya sekitar 50\% saja yang lulus dari kriteria ketuntasan minimal yang telah ditentukan. Hasil tes menulis siswa pada pratindakan dapat dilihat pada tabel 1.

Tabel 1. Hasil Tes Menulis Surat Pribadi

\begin{tabular}{ccccc}
\hline $\begin{array}{c}\text { Skor } \\
\text { Ideal }\end{array}$ & KKM & $\begin{array}{c}\text { Skor yang didapat } \\
\text { siswa }\end{array}$ & Banyaknya Siswa & Persentase \% \\
\hline \multirow{3}{*}{100} & $\leq 50$ & 10 & $37,03 \%$ \\
& & $51-65$ & 7 & $25,92 \%$ \\
& 66 & $61-80$ & 5 & $18,52 \%$ \\
& & & 5 & $18,52 \%$ \\
& Jumlah & & 27 & $100 \%$ \\
\hline
\end{tabular}

Berdasarkan data pada tabel 1 menunjukkan bahwa siswa yang memperoleh skor mencapai KKM hanya 10 siswa yang artinya hanya $37,03 \%$ siswa yang sudah mampu menulis surat pribadi degan 
baik dan benar. Dengan demikian masih ada 17 orang siswa yang belum tuntas dalam pembelajaran menulis surat pribadi.

Untuk mengatasi masalah tersebut, maka penulis dan guru mata pelajaran merancang pembelajaran pada siklus 1 dengan menggunakan media lagu. Adapun lagu yang dipilih adalah lagu "Bunda" karya Melly Goselow.

Kegiatan pembelajaran pada siklus I tetap dilaksanakan secara daring, yaitu menggunakan aplikasi google clasroom untuk siswa mengirimkan surat yang telah dibuat sebagai tugas rumah. Sedangkan aplikasi zoom digunakan untuk memberikan penjelasan materi yang kemudian disertai dengan pemutaran lagu "Bunda". Hasil pembelajaran siklus I dapat dilihat pada tabel 2.

Tabel 2. Hasil Tes Siswa Menulis Surat Pribadi dengan menggunakan media lagu "Bunda" karya Melly Goeslow siklus I

\begin{tabular}{ccccc}
\hline $\begin{array}{c}\text { Skor } \\
\text { Ideal }\end{array}$ & KKM & $\begin{array}{c}\text { Skor yang didapat } \\
\text { siswa }\end{array}$ & Banyaknya Siswa & Persentase \% \\
\hline \multirow{3}{*}{100} & $\leq 50$ & 6 & $22,22 \%$ \\
& & $51-65$ & 4 & $14,81 \%$ \\
& 66 & $61-80$ & 7 & $25,92 \%$ \\
& & & 10 & $37,03 \%$ \\
& Jumlah & & 27 & $100 \%$ \\
\hline
\end{tabular}

Data pada tabel siklus I menunjukkan peningkatan jumlah siswa yang memperoleh skor diatas KKM yaitu 17 siswa yang artinya sudah lebih dari 50\% siswa mengalami peningkatan dalam menulis surat pribadi. Akan tetapi, bila melihat dari indikator ketercapaian penelitian siklus belum dapat dihentikan. Dari hasil wawancara dengan siswa ditemukan ada beberapa siswa yang kurang memiliki kedekatan dengan ibu sehingga lagu "Bunda" yang digunakan sebagai media pembelajaran dirasa masih kurang memotivasi untuk menulis surat pribadi dengan baik. Dengan demikian, maka dilasanakan kembali siklus yang ke II, yang mana siklus II peneliti dan guru mata pelajaran menggunakan media lagu “Titip Rindu Buat Ayah" Karya Ebiet G. Ade.

Secara garis besar, pelaksanaan pembelajaran pada siklus II sama seperti siklus I, yang membedakan hanya media lagu yang digunakan. Hasil pembelajaran siklus II dilihat pada tabel 3.

Tabel 3. Hasil Tes Siswa Menulis Surat Pribadi dengan menggunakan media lagu "Titip Rindu Buat Ayah" karya Ebiet G. Ade siklus II

\begin{tabular}{ccccc}
\hline $\begin{array}{c}\text { Skor } \\
\text { Ideal }\end{array}$ & KKM & $\begin{array}{c}\text { Skor yang didapat } \\
\text { siswa }\end{array}$ & Banyaknya Siswa & Persentase \% \\
\hline \multirow{3}{*}{100} & & $\leq 50$ & 2 & $7,40 \%$ \\
& & $51-65$ & 1 & $3,70 \%$ \\
& 66 & $61-80$ & 9 & $33,33 \%$ \\
& & & 15 & $55,56 \%$ \\
& Jumlah & & $\mathbf{2 7}$ & $\mathbf{1 0 0 \%}$ \\
\hline
\end{tabular}

Berdasarkan tabel 3 dapat dilihat bahwa terjadi peningkatan siswa dalam menulis surat pribadi dengan menggunakan media lagu. Sebanyak 15 siswa sudah memperoleh skor lebih dari 80 dan 9 siswa memperoleh skor lebih dari KKM. Dengan demikian dapat dikatakan bahwa penggunaan lagu dalam meningkatkan kemampuan menulis surat pribadi siswa dinyatakan efektif. Meskipun demikian, masih terdapat 3 siswa yang memperoleh skor kurang dari KKM. Informasi dari hasil wawancara yang diperoleh peneliti dan guru mata pelajaran terhadap 3 siswa tersebut adalah siswa tidak menyukai lagu dengan jenis seperti yang digunakan sebagai media pembelajaran, siswa tersebut memang tidak suka menulis dan siswa terakhir menyatakan kesulitan dalam belajar daring.

Bersadasarkan tindakan siklus I dan II diperoleh data yang menunjukkan adanya peningkatan dalam menulis surat pribadi pada siswa kelas VII SMP Nusantara Indah. Peningkatan tersebut dapat dilihat pada gambar 1 . 


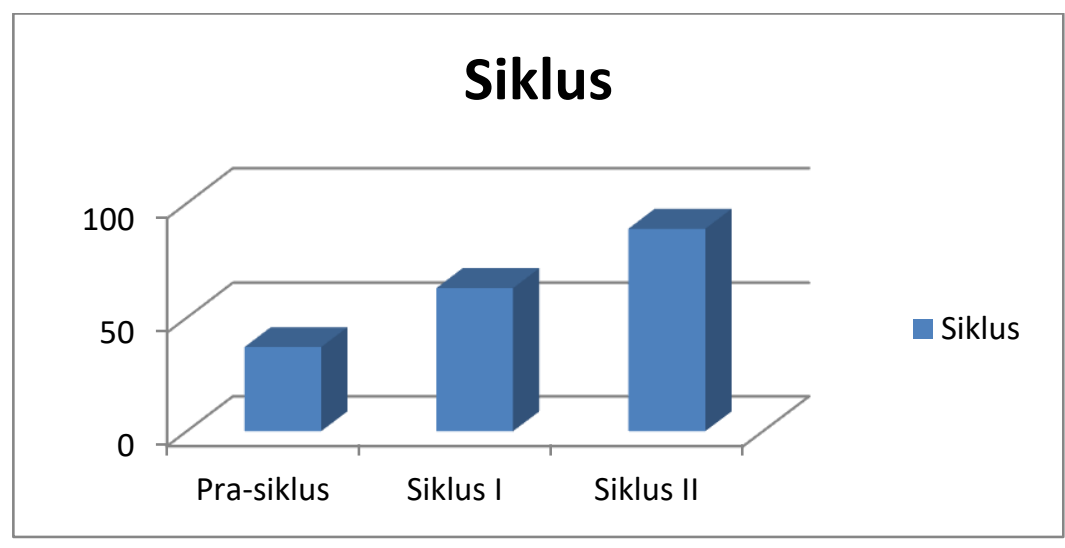

Gambar 1. Peningkatan Kemampuan Siswa Dalam Menulis Surat Pribadi

\section{Kesimpulan}

Berdasarkan hasil penelitian, dapat disimpulkan bahwa penggunaan media lagu sebagai upaya meningkatkan kemampuan menulis surat pribadi siswa SMP Nusantara Indah dinyatakan efektif. Hal tersebut dapat dilihat dari peningkatan persentasi hasil skor siswa diatas KKM dalam menulis surat pribadi pada pra-siklus 37,04\%, pada siklus I setelah tindakan mengalami kenaikan yaitu 62,95\% dan pada siklus ke II jumlah siswa yang memperoleh skor di atas KKM meningkat menjadi 88.89\%. Dari hasil wawancara, siswa menyatakan menggunakan lagu sangat membantu dalam meningkatkan kemampuan menulis surat pribadi.

\section{Daftar Pustaka}

Aizid, R. (2011).Sehat dan Cerdas dengan Terapi Musik.Yogyakarta: Laksana.

Andyani, N., Saddhono, K., \& Mujyanto, Y. (2017). Peningkatan kemampuan menulis teks eksplanasi dengan menggunakan media audiovisual pada siswa sekolah menengah pertama. Basastra, 4(2), $161-174$.

Baidowi, A., Sumarmi, S., \& Amirudin, A. (2016). Pengaruh model pembelajaran berbasis proyek terhadap kemampuan menulis karya ilmiah geografi siswa sma. Jurnal Pendidikan Geografi, 20(1).

Darmuki, A., Hariyadi, A., \& Hidayati, N. A. (2021). Peningkatan Kemampuan Menulis Karya Ilmiah Menggunakan Media Video Faststone di Masa Pandemi COVID-19. Jurnal Educatio FKIP UNMA, 7(2), 389-397.

Fajriah, F. (2017). Strategi Pembelajaran Maharah Al-Kitabah Pada Tingkat Ibtidaiyah. Pionir: Jurnal Pendidikan, 6(2).

Heryaneu, Y. (2014). Efektivitas Penggunaan MediaScrapbook untuk Meningkatkan Kemampuan Menulis Karangan Deskripsi (Doctoral dissertation, Universitas Pendidikan Indonesia).

Jumaryatun, Mulyono,SW., Anindyarini, A. (2104). Penggunaan Media Lagu Sebagai Upaya Meningkatkan Motivasi Dan Kemampuan Menulis Cerpen. Basastra Jurnal Penelitian Babasa, Sastra Indonesia dan Pengajarannya, 1 (3).

Kasili, R. M., Barasandji, S., \& Ulfah, U. (2017). Peningkatan Kemampuan Menulis Surat Pribadi Melalui Metode Latihan Terbimbing Siswa Kelas V SD Inpres Tomoli Selatan. Jurnal Kreatif Online, 5(3).

Lestari, dkk. (2005). Pembelajaran Bahasa dan sastra Indonesia. Klaten PT. Intan paliwara :Paramitra.

Maryam, M. M. (2016). Pengelolaan Pembelajaran Bahasa Indonesia Siswa SD Melalui Teknik Reka Cerita Gambar. Manajer Pendidikan, 10(2). 
Mundziroh, S., Sumarwati, S., \& Saddhono, K. (2013). Peningkatan kemampuan menulis cerita dengan menggunakan metode picture and picture pada siswa sekolah dasar. Basastra, 1(2), 318-327.

Salfera, N. (2017). Meningkatkan kemampuan menulis teks eksplanasi dengan menggunakan media gambar berseri pada siswa kelas VII. Jumal EDUCATIO: Jumal Pendidikan Indonesia, 3(2), 3243.

Samsudin, A. (2012). Peningkatan Kemampuan Menulis Eksposisi Berita Dan Menulis Eksposisi Ilustrasi Siswa Kelas V Melalui Model Pembelajaran Kooperatif Terpadu Membaca Dan Menulis. Jurnal Penelitian Pendidikan, 13(2), 1-11.

Sanjaya, W. (2011). Penelitian Tindakan Kelas.Jakarta: Prenada Media Group.

San Fauziya, D. (2018). Pembelajaran kooperatif melalui teknik duti-duta dalam meningkatkan kemampuan menulis argumentasi. Riksa Bahasa: Jurnal Bahasa, Sastra, dan Pembelajarannya, 2(2).

Sianturi, H. S. (2012). Metode Latihan Terbimbing sebagai Upaya untuk Meningkatkan Kemampuan Berpikir Kritis-Kreatif dalam Pembelajaran Menulis Cerpen. Basastra, 1(1).

Sukiman. (2011). Penelitian Tindakan Kelas untuk Guru Pembimbing (Bimbingan dan Konseling). (Cetakan Pertama). Yogyakarta: Paramitra

Tarigan, H. G. (2008). Membaca Sebagai Suatu Keterampilan Berbahasa. Bandung: Angkasa.

Trismanto, T. (2017). Keterampilan Menulis Dan Permasalahannya. Bangun Rekaprima: Majalab Ilmiah Pengembangan Rekayasa, Sosial dan Humaniora, 3(1, April), 62-67. 